\title{
The Metaphysics of Consciousness
}

Royal Institute of Philosophy Supplement: 67

Edited by Pierfrancesco Basile, Julian Kiverstein \& Pauline Phemister 


\section{Royal Institute of Philosophy Supplements}

The Royal Institute of Philosophy Supplements are published twice a year. Institutional subscribers to the journal Philosophy receive the supplements as part of their subscription. The following supplements are available to purchase as books.

\begin{tabular}{|c|c|c|}
\hline blume 37 & 1994 & $\begin{array}{l}\text { Philosophy, Psychology and } \\
\text { Psychiatry }\end{array}$ \\
\hline 38 & 1995 & Philosophy and Technology \\
\hline 39 & 1995 & $\begin{array}{l}\text { Karl Popper: Philosophy and } \\
\text { Problems }\end{array}$ \\
\hline 40 & 1996 & Philosophy and Pluralism \\
\hline 41 & 1996 & Verstehen and Human Understanding \\
\hline 42 & 1997 & Thought and Language \\
\hline 43 & 1998 & $\begin{array}{l}\text { Current Issues in Philosophy } \\
\text { of Mind }\end{array}$ \\
\hline 44 & 1999 & German Philosophy since Kant \\
\hline 45 & 1999 & Philosophy and Public Affairs \\
\hline 46 & 2000 & Logic, Cause \& Action \\
\hline 47 & 2000 & $\begin{array}{l}\text { Philosophy, the Good, the True } \\
\text { and the Beautiful }\end{array}$ \\
\hline 48 & 2001 & Philosophy at the New Millennium \\
\hline 49 & 2001 & Naturalism, Evolution and Mind \\
\hline 50 & 2002 & Time, Reality \& Experience \\
\hline 51 & 2002 & Logic, Thought and Language \\
\hline 52 & 2003 & Philosophy and the Emotions \\
\hline 53 & 2003 & Minds and Persons \\
\hline 54 & 2004 & Modern Moral Philosophy \\
\hline 55 & 2004 & Agency and Action \\
\hline 56 & 2005 & Philosophy, Biology and Life \\
\hline 57 & 2005 & The Philosophy of Need \\
\hline 58 & 2006 & Political Philosophy \\
\hline 59 & 2006 & Preferences and Well-Being \\
\hline 60 & 2007 & Narrative and Understanding Persons \\
\hline 61 & 2007 & Philosophy of Science \\
\hline 62 & 2008 & $\begin{array}{l}\text { Being: Developments in } \\
\text { Contemporary Metaphysics }\end{array}$ \\
\hline 63 & 2008 & $\begin{array}{l}\text { Kant and Philosophy } \\
\text { of Science Today }\end{array}$ \\
\hline 64 & 2009 & Epistemology \\
\hline 65 & 2009 & Conceptions of Philosophy \\
\hline 66 & 2010 & Philosophy as Therapeia \\
\hline
\end{tabular}

(ISBN 0521469023)

(ISBN 0521558166)

(ISBN 0521558158)

(ISBN 0521567505)

(ISBN 0521587425)

(ISBN 0521587417)

(ISBN 0521639271)

(ISBN 0521667828)

(ISBN 0521667844)

(ISBN 0521785103)

(ISBN 0521785111)

(ISBN 0521005086)

(ISBN 0521003733)

(ISBN 0521529670)

(ISBN 0521529662)

(ISBN 0521537347)

(ISBN 0521537339)

(ISBN 0521603269)

(ISBN 0521603560)

(ISBN 0521678455)

(ISBN 0521678447)

(ISBN 0521695597)

(ISBN 0521695589)

(ISBN 9780521714099)

(ISBN 9780521718967)

(ISBN 9780521735445)

(ISBN 9780521748513)

(ISBN 9780521138581)

(ISBN 9780521138574)

(ISBN 9780521165150)

From Volume 13 onwards the Series is published by Cambridge University Press and some earlier titles are also available.

This journal issue has been printed on FSC-certified paper and cover board. FSC is an independent, non-governmental, not-for-profit organization established to promote the responsible management of the world's forests. Please see www.fsc.org for information. 


\section{The \\ Metaphysics \\ of \\ Consciousness}

ROYAL INSTITUTE OF PHILOSOPHY SUPPLEMENT: 67

EDITED BY

Pierfrancesco Basile Julian Kiverstein Pauline Phemister

\section{CAMBRIDGE UNIVERSITY PRESS}


PUBLISHED BY THE PRESS SYNDICATE OF THE UNIVERSITY OF CAMBRIDGE

The Pitt Building, Trumpington Street, Cambridge, CB2 1RP, United Kingdom

CAMBRIDGE UNIVERSITY PRESS

The Edinburgh Building, Cambridge CB2 8RU, United Kingdom

32 Avenue of the Americas, New York, NY 10013-2473, USA

477 Williamstown Road, Port Melbourne, VIC 3207, Australia Ruiz de Alarcón 13, 28014 Madrid, Spain

Dock House, The Waterfront, Cape Town 8001, South Africa

(C) The Royal Institute of Philosophy and the contributors 2010

Printed in the United Kingdom at the University Press, Cambridge Typeset by Techset Composition Ltd, Salisbury, UK

A catalogue record for this book is available from the British Library ISBN 9780521173919

ISSN 1358-2461 


\section{Contents}

Notes on Editors and Contributors $\quad$ V

Preface 1

Sprigge's Ontology of Consciousness 5

LEEMON MCHENRY

How to Become Unconscious 21

STEPHEN R. L. CLARK

The Road to Substance Dualism 45

GEOFFREY MADELL

Fundamental Singleness: How to Turn the 2nd Paralogism

into a Valid Argument

GALEN STRAWSON

It Must be True - But How Can it Be? Some Remarks on

Panpsychism and Mental Composition

PIERFRANCESCO BASILE

Phenomenal Holism

BARRY DAINTON

Is There a Metaphysics of Consciousness Without a

Phenomenology of Consciousness? Some Thoughts Derived from

Husserl's Philosophical Phenomenology EDUARD MARBACH

Making Sense of Phenomenal Unity: An Intentionalist Account of

Temporal Experience

JULIAN KIVERSTEIN

Time in Consciousness, Consciousness in Time

DAVID COCKBURN

Quality, Thought and Consciousness

HOWARD ROBINSON

Concessionary Dualism and Physicalism

WILLIAM SEAGER

The Representational vs. the Relational View of Visual Experience BRIAN P. MCLAUGHLIN

Consciousness: Don't Give Up on the Brain KENNETH AIZAWA

Index of Names 


\section{Notes on Editors and Contributors}

KENNETH AIZAWA

Kenneth Aizawa is the Charles T. Beaird Professor of Philosophy at Centenary College of Louisiana. He is the author of The Systematicity Arguments (2003) and, with Fred Adams, The Bounds of Cognition (2008).

\section{PIERFRANCESCO BASILE}

Pierfrancesco Basile teaches Philosophy at the University of Bern, Switzerland. His publications include two books, Experience and Relations: An Examination of F. H. Bradley's Conception of Reality (1999) and Leibniz, Whitehead and the Metaphysics of Causation (2009), as well as several essays on issues in metaphysics, process thought, British idealism and early analytic philosophy.

\section{STEPHEN R. L. CLARK}

Stephen R. L. Clark was Professor of Philosophy at the University of Liverpool. His books include The Nature of the Beast (1982), Animals and their Moral Standing (1997), Biology and Christian Ethics (2006), G. K. Chesterton: Thinking Backwards, Looking Forwards (2006) and Understanding Faith: Religious Belief and Its Place in Society (2009).

\section{DAVID COCKBURN}

David Cockburn is Professor of Philosophy at the University of Wales, Lampeter. His publications include Other Human Beings (1990), Other Times: Philosophical Perspectives on Past, Present and Future (1997), and An Introduction to the Philosophy of Mind (2001). He edited the Royal Institute of Philosophy volume on Human Beings (1991), and has published a wide range of papers on themes in philosophy of mind, ethics, Wittgenstein, philosophy of religion, and philosophy of time.

\section{BARRY DAINTON}

Barry Dainton is Professor of Philosophy at the University of Liverpool. His publications include Stream of Consciousness (2000, 2nd edition 2006), Time and Space (2001, 2nd edition 2010), and The Phenomenal Self (2008). 


\section{JULIAN KIVERSTEIN}

Julian Kiverstein is a Teaching Fellow in Philosophy at the University of Edinburgh. The author of a number of papers on consciousness, temporality and the self, he is also editing Heidegger and Cognitive Science (2010, with Michael Wheeler) and Decomposing the Will (2010, with Tillmann Vierkant and Andy Clark).

\section{GEOFFREY MADELL}

Geoffrey Madell was Senior Lecturer in Philosophy at Edinburgh University. He is the author of The Identity of the Self (1981), Mind and Materialism (1988) and Philosophy, Music and Emotion (2002). He has published numerous articles on the philosophy of mind, particularly on the issues of personal identity and the mind-body problem.

\section{EDUARD MARBACH}

Eduard Marbach was Professor of Philosophy at the University of Bern, Switzerland. His publications include Das Problem des Ich in der Phänomenologie Husserls (1974), Mental Representation and Consciousness: Towards a Phenomenological Theory of Representation and Reference (1993), and An Introduction to Husserlian Phenomenology (1993, co-authored with Rudolf Bernet and Iso Kern). He has edited Husserl's Phantasie, Bildbewusstsein, Erinnerung. Zur Phänomenologie der anschaulichen Vergegenwärtigungen (1980, Husserliana, Vol. 23) and is the author of several papers on phenomenology and the philosophy of mind.

\section{LEEMON MCHENRY}

Leemon McHenry teaches Philosophy at California State University, Northridge. His books include Whitehead and Bradley: A Comparative Analysis (1992), Consciousness, Reality and Value: Essays in Honour of T. L. S. Sprigge (2007, co-edited with Pierfrancesco Basile), and British Philosophers, 1800-2000 (2002, co-edited with Philip Dematteis and Peter Fosl). He is the author of numerous articles and book chapters on topics in metaphysics, philosophy of science and medical ethics.

\section{BRIAN P. MCLAUGHLIN}

Brian P. McLaughlin is Professor II in the Philosophy Department at Rutgers University and a member of the Executive Council of the Rutgers University Cognitive 
Science Center. He has published numerous articles in a wide range of fields in philosophy. Recently, he was a co-editor of Contemporary Debates in the Philosophy of Mind (2007) and a co-editor of The Oxford Handbook of Philosophy of Mind (2009).

\section{PAULINE PHEMISTER}

Pauline Phemister is Reader in Philosophy at the University of Edinburgh. Her publications include The Rationalists: Descartes, Spinoza and Leibniz (2006) and Leibniz and the Natural World: Activity, Passivity and Corporeal Substances in the Philosophy of Leibniz (2005). She has published widely on topics in early modern philosophy, especially in the areas of metaphysics, ethics, and mind-body relations.

\section{HOWARD ROBINSON}

Howard Robinson is University Professor at Central European University, Budapest. He is author of Matter and Sense (1982, re-issued in paperback 2009) and Perception (1994), editor of the World's Classics edition of Berkeley's 'Principles' and 'Three Dialogues', and of various recent articles and book chapters on the philosophy of perception, the mind-body problem and idealism.

\section{WILLIAM SEAGER}

William Seager is Professor of Philosophy at the University of Toronto. He has published many articles in the philosophy of mind and two books on consciousness, Metaphysics of Consciousness (1991) and Theories of Consciousness (1999).

\section{GALEN STRAWSON}

Galen Strawson teaches in the Philosophy Department at the University of Reading and is a regular visitor at the Philosophy Program at the City University of New York Graduate Center. He is the author of Selves: An Essay in Revisionary Metaphysics (2009), Real Materialism and Other Essays (2008), Mental Reality (1994, new edition 2009), The Secret Connexion: Realism, Causation and David Hume (1989), and Freedom and Belief (1986, new edition 2010). 